\begin{tabular}{l|c|c}
\hline ISSN: 0001-5113 & ACTA ADRIAT., \\
AADRAY & $60(1): 103-106,2019$ & SHORT COMMUNICATION \\
\hline
\end{tabular}

\title{
Captures of Molva molva (Linnaeus, 1758) still happen in NW Mediterranean waters
}

\author{
Diego K. KERSTING ${ }^{1,2^{*}}$ and Ernesto AZZURRO ${ }^{3,4}$ \\ ${ }^{1}$ Departament de Biologia Evolutiva, Ecologia i Ciències Ambientals, Institut de Recerca de la \\ Biodiversitat, Universitat de Barcelona, Barcelona, Spain \\ ${ }^{2}$ Working Group on Geobiology and Anthropocene Research, Institute of Geological Sciences, \\ Freie Universität Berlin, Berlin, Germany
}

${ }^{3}$ ISPRA, National Institute of Environmental Protection and Research, Sts Livorno, Piazzale dei Marmi 2, 57123 Livorno, Italy

${ }^{4}$ SZN - Stazione Zoologica Anton Dohrn Naples, Villa Comunale, 80121 Napoli, Italy

Corresponding author, e-mail: kersting@zedat.fu-berlin.de

The ling Molva molva is a widespread gadid in the Northeast Atlantic and one example of a poorly studied species of particular interest, being its distribution affected by climate warming. The ling supposedly occurs in the cold waters of the Northwestern Mediterranean Sea, where it used to be commonly fished, but to our best knowledge, records of M. molva after the 1990s are not available from the scientific literature. Here we report the recent capture of two individuals, one of them of considerable size, at 35 nautical miles off the coast of Castelló (Spain, NW Mediterranean).

Key words: ling, Molva molva, NW Mediterranean, fishermen knowledge

\section{INTRODUCTION}

The ling, Molva molva (Linnaeus, 1758), is a boreal gadid fish, widely distributed in the North Atlantic and from southern Greenland to Canada. It is a long living species, with a lifespan exceeding 20 years and sizes up to 200 $\mathrm{cm}$ in total length (SVETOVIDOV, 1986). Fisheries have exploited the ling for centuries in the North Atlantic (GONZALEZ et al., 2015), most significantly as a target of longline fisheries, but M. molva is also a valued bycatch in other fisheries. In the Mediterranean Sea, the occurrence of this species is considered to be strictly restricted to the NW basin, where it used to be commonly fished along the Catalan coasts (LLORET et al., 2015). Nevertheless, according to LLORET et al. (2015) landings of M. molva off the Catalan coast (NW Mediterranean) ceased in the 1990s and reasonable concern can be expressed on the status of this cold-water species in relation to climate change scenarios. Here we report new information on the recent capture of two individuals in the NW Mediterranean Sea.

\section{MATERIAL AND METHODS}

In December 2015, during two consecutive days, two individuals of M. molva were captured by a longliner in two nearby located fishing 
grounds located at around 35 nautical miles off the coast of Castelló (Spain, NW Mediterranean). The largest ling (Fig. 1) was collected at $260 \mathrm{~m}$ depth (geographical coordinates: $39^{\circ} 40^{\prime} 860^{\prime \prime} \mathrm{N}, 00^{\circ} 39^{\prime} 441^{\prime \prime} \mathrm{E}$ ), it weighted 13.5 $\mathrm{kg}$ and measured $160 \mathrm{~cm}$. The other individual was fished the day before in a nearby located area at $400 \mathrm{~m}$ depth (geographical coordinates: $40^{\circ} 09^{\prime} 340$ 'N, $\left.01^{\circ} 10^{\prime} 053^{\prime \prime} \mathrm{E}\right)$ and it weighted $1.5 \mathrm{~kg}$. Pictures, description and information on the captures, were gathered through interviews with the crew of the professional longliner vessel Panollo Segundo, which collected the ling. The identification of both the individuals was based on the pictures reported in Fig. 1.
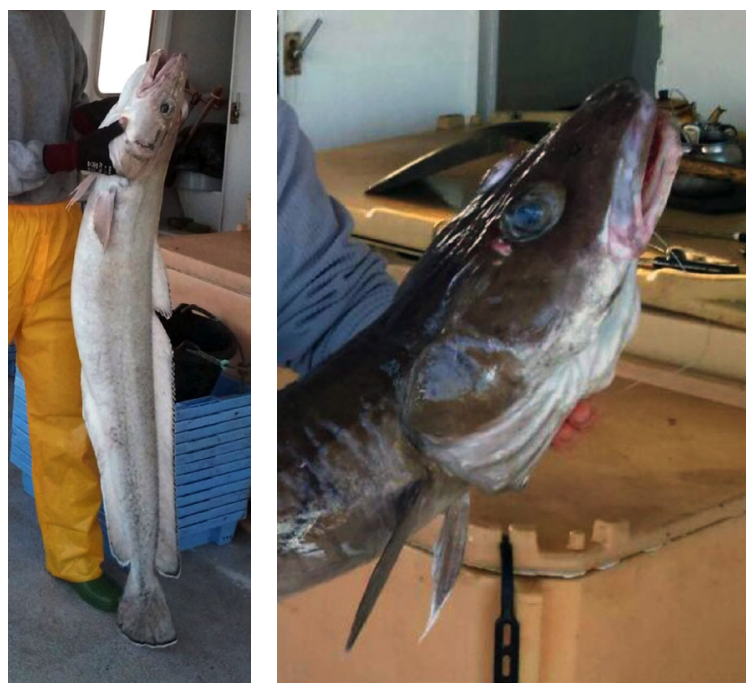

Fig. 1. Large specimen of Molva molva caught by a long liner at 35 nautical miles off the coast of Castelló (Spain, NW Mediterranean). Date: 30th December 2015. Geographical coordinates: $39^{\circ} 40^{\prime} 860^{\prime \prime} \mathrm{N}$, $00^{\circ} 39$ '4 41 ' $E$

\section{RESULTS AND DISCUSSION}

To our best knowledge, the reported captures stand for the first documented evidence of the occurrence of M. molva in the Spanish Mediterranean waters since the 1990 s.

Pictures allowed recognizing some taxonomical characters of this species: the prominent upper jaw and the caudal fin, with white and black terminal margins. According to LLORIS (2015), these traits suffice to distinguish M. molva from other congeneric species (e.g., M. mac- rophtalma). Fishermen also described the occurrence of a barbell in the chin, which was barely noticeable in Fig. 1. According to the fishermen, the species was completely unfamiliar to them and they had never caught it before.

Considering that M. molva is a poorly studied species, this new observation has a certain relevance for the knowledge of its distribution. This may be especially true in the context of climate change, since this cold-water fish is known to be retreating its distribution as a natural response to seawater warming (PERRY et al., 2005). While historical data in North Atlantic waters highlighted significant declines in ling abundances (see GONZALEZ et al., 2005 for a revision), very scarce information exists on the recent occurrence of this species in the Mediterranean Sea (BIAGI et al., 2002, MAYNOU et al., 2012). LLORET et al. (2015) reported that catches of M. molva ceased in the Catalan Sea (NW Mediterranean) in the 1990s. These authors also considered the status of M. molva in the Mediterranean as critical, classifying the ling as being in the "disappearance from the catch" phase. Nevertheless, the here-reported observation of two individuals off the southern Catalan coasts shed light on the presence of large M. molva in the area, providing an important, though punctual information on the current occurrence of this species in the NW Mediterranean Sea. Present findings also highlight the strategic importance of fishermen in detecting the occurrence of rare and poorly known megafauna (AZZURRO et al., 2018). Certainly, future information are needed to clarify if the Castelló individuals were vagrant fish or if they belonged to a permanent population, which could hopefully still exist in the area.

\section{AKNOWLEDGEMENTS}

We kindly appreciate the collaboration and information kindly provided by the captain and crew of the longliner PANOLLO SEGUNDO and by X. DEL SEÑOR. We also warmly acknowledge our colleague Domingo LLORIS SAMO for the valuable comments received and the useful suggestions of two anonymous reviewers. 


\section{REFERENCES}

AZZURRO, E., L. BOLOGNINI, B. DRAGIČEVIĆ, D. DRAKULOVIĆ, J. DULČIĆ, E. FANELLI, F. GRATTI, J. KOLITARI, L. LIPEJ, E. MAGALETTI, O. MARKOVIĆ, S. MATIĆ-SKOKO, B. MAVRIĆ, N. MILONE, A. JOKSIMOVIĆ, J. TOMANIĆ, A. SCARPATO, P. TUTMAN, D. VRDOLJAK \& F. ZAPPACOSTA. 2018. Detecting the occurrence of indigenous and non-indigenous megafauna through fishermen knowledge: A complementary tool to coastal and port surveys. Mar. Pollut. Bull., https://doi.org/10.1016/j. marpolbul.2018.01.016

BERGSTAD O. A. \& N. R. HAREIDE. 1996. Ling, blue ling, and tusk of the North-East Atlantic. Fisken og Havet., 15: 1-126.

BIAGI, F., P. SARTOR, G. D. ARDIZZONE, P. BELCARI, A. BELLUSCIO \& F. SERENA. 2002. Analysis of demersal fish assemblages of the Tuscany and Latium coasts (north-western Mediterranean). Sci. Mar., 66: 233-42.

GONZALEZ, E. B., H. KNUTSEN, P. E. JORDE, K. A. GLOVER \& O. A. BERGSTAD. 2015. Genetic analyses of ling (Molva molva) in the Northeast Atlantic reveal patterns relevant to stock assessments and management advice. ICES J. Mar. Sci., 72: 635-641.
LLORET J., A. SABATÉS, M. MUÑOZ, M. DEMESTRE, I. SOLÉ, T. FONT, M. CASADEVALL, P. MARTÍN \& S. GÓMEZ. 2015. How a multidisciplinary approach involving ethnoecology, biology and fisheries can help explain the spatiotemporal changes in marine fish abundance resulting from climate change. Glob. Ecol. Biogeogr., 24: 448-461.

LLORIS, D. 2015. Ictiofauna marina. Manual de identificación de los peces marinos de la península Ibérica y Baleares. Omega Ed., Barcelona, Spain, 674 pp.

MAYNOU, F. \& J. E. CARTES. 2012. Effects of trawling on fish and invertebrates from deep-sea coral facies of Isidella elongata in the western Mediterranean. J. Mar. Biol. Assoc. U. K., 92: 1501-1507.

PERRY, A. L., P. J. LOW, J. R. ELLIS \& J. D. REYNOLDS. 2005. Climate change and distribution shifts in marine fishes. Science, 308: 19121915.

SVETOVIDOV, A.N. 1986. Gadidae. In: P. J. P. Whitehead, M-L. Bauchot, J-C. Hureau, J. Nielsen \& E. Tortonese (Editors). Fishes of the North-Eastern Atlantic and Mediterranean, II. Unesco, Paris, pp. 680-710. 


\section{Ulovi manjića morskog, Molva molva (Linnaeus, 1758) se i dalje događaju u sjeverozapadnom dijelu Sredozemnog mora}

Diego K. KERSTING i Ernesto AZZURRO

Kontakt e-pošta: kersting@zedat.fu-berlin.de

\section{SAŽETAK}

Manjić morski (Molva molva) je široko rasprostranjena vrsta u sjeveroistočnom Atlantiku i jedan od primjera slabo istraženih vrsta od posebnog interesa zbog njegove rasprostranjenosti koja je pod utjecajem zagrijavanja klime.

Manjić morski se navodno pojavljuje u hladnim vodama sjeverozapadnog Sredozemnog mora, gdje je nekad bio uobičajeni ulov, ali prema našim saznanjima, zapisi o Molva molva nakon 1990-ih nisu dostupni iz znanstvene literature.

U ovom radu navodimo nedavni ulov dvije jedinke, od kojih je jedna znatne veličine, na 35 nautičkih milja od obale Castelló (Španjolska).

Ključne riječi: manjić morski, Molva molva, sjeverozapadno Sredozemlje, znanje ribara 